and nonpathogenic somatic material, or is caused by the clumping of some of the smaller microchromosomes.

YAMASHINA ${ }^{B}$ has reported a constant diploid number of 78 and 77 chromosomes from the somatic and the germ cells of the male and female respectively. Newcomer ${ }^{7,8}$ on the other hand, describes the microchromosomes as nonchromosomal, the diploid number for the male and female being 12 and 11 respectively. Recent studies by vaN BRINK ${ }^{9}$, OHNO ${ }^{5}$ and KRISHAN ${ }^{10}$ have, however, established the chromosomal nature of these bodies, though their number, according to them, is not as constant as reported by Japanese workers. The range of numerical variation, according to VAN BRINK ${ }^{9}$ and OHNO ${ }^{5}$, is from 67 to 82 .

It seems that the haploid chromosome number in the male germ cells of the domestic fowl is 39 and deviations from this number may be due to the clumping of some of the microelements. In fact KRISHAN ${ }^{10}$ has recorded 39 chromosomes in more than $50 \%$ of the first meiotic metaphase plates and OHNO $^{5}$ has found the same number in all the ten plates he counted. Somatic cells, in contrast to the germ cells, show a great variation in the chromosome number, which cannot be attributed to clumping alone. This view is in contrast to that of MATTHEY and VAN BRINK, as reported by OHNO ${ }^{5}$, who believe that the micro- chromosomes are not inconstant in their number but that their exact determination is a difficult technical problem.

It looks probable that the microchromosomes show a variation in their number which within certain limits is inherent in the material but beyond that is caused by our technical failure to prevent the clumping of these refractory boclies ${ }^{12}$.

Zusammenfassung. Beschreibung der somatischen Chromosomen des Haushuhns nach Colchicinbehandlung. Wie Chromosomenzahl schwankt zwischen 39 und $76.50^{\circ}$, der Chromosomenplatten haben Zahlen zwischen o0 und 70 . Die Makrochromosomen zeigen keine Abweichung in der Zahl. Die Zahlvariationen sind hauptsächlich durch dic Mikrochromosomen bedingt.

1. KRISHAN

Deparment of Zoology, Pranjal l'niversity, Chandigarh (Punjab, India), April 1, I062.

12 I am highly thankful to 1)r. ( $x$. l'. Suskna, Panjab lniverity, for his kind supervinion, helpful erieism and laboratory facilitis.

\section{Role of Cell Division in Gastrulation of the Hemiramphid Dermogenys pusillus Van Hasselt}

Morphogenetical movements in gastrulation of the Cyprinodonts Fundulus heteroclitus and Xiphophorus hellevi occur in a normal fashion in cases in which cytokinesis is prevented by treatment with the antimitotic alkaloid colchicine ${ }^{1,2}$. To establish whether a more general significance should possibly be attached to this phenomenon, a corresponding investigation was performed with the halfbeak Dermogenys pusillus Van Hasselt (Hemiramphidae). For this purpose pregnant females in the first phase of gestation were injected intraperitoneally with $0.5 \mathrm{ml}$ of $0.001 M$ colchicine solution. As in Fundulus and Xiphophorts $^{2}$ during gastrulation in stage 12 (beginning gastrula), 13 (advanced gastrula), 14 (further advanced gastrula) and 15 (closure of blastopore) both treated and control females were killed by decapitation and the ovaries were fixed in Bouin's fluid. The blastoderms were sectioned at $5 \mu$ and stained with Heidenhain's iron haematoxylin. The mitotic indices representing the ratio of cells in mitosis to the total number of cells and expressed as $\%$, were determined in each blastoderm on the basis of cell counts of the sections. As in Fundulus ${ }^{1}$ and Xiphophorus ${ }^{2}$, also in Dermogenys ${ }^{3}$ the colchicine treat-

Mitotic indices of colchicine-treated and control embryos of $D_{k}+m o-$ genys pusillus. Stage $12=$ begiming gastrula, $1: 3=$ advanced gastrula, $14=$ further advanced gastrula, $15=$ closure of blastopore.

\begin{tabular}{|c|c|c|}
\hline Stazye & $\begin{array}{l}\text { Witotic inde } x(\%) \\
\text { Colehicine treatment }\end{array}$ & Cintutal \\
\hline 12 & fi..$X$ & 2.1 \\
\hline 13 & 15.9 & 2.5 \\
\hline 14 & 20.7 & $3: 2$ \\
\hline 15 & $3 \vec{i}, 4$ & 3.5 \\
\hline
\end{tabular}

ment did not have any apparent effect on gastrulation, which was similar to that in control blastolerms and consequently morphologically normal. In the colchicinetreated blastoderms, typical $c$-mitoses were observed. On the strength of the mitotic index determinations for colchicine-treated and control blastoderms, the number of $c$-mitoses increased, indicating that mitosis was completely blocked. The results are given in the Table. Thus, in stage 15 $37.4^{\circ} .0$ of the cells are in mitosis, while the mitotic indices of control blastoderms are relatively low during gastrulation. Consequently, also in early morphogenesis cell division can be dismissed as a causative factor and apparently provides only material for morphogenetic movements ${ }^{4}$. These results, corresponding very well with the findings of KESsEL obtained with Fundulus and therefore of more general importance, are no doubt an argument for the view that gastrulation is a problem of mass movements and not of growth ${ }^{5,6}$.

Zusammenfassung. Mit Colchicin wird die Bedeutung der Mitose für die (rastrulation des HemiramphusFisches Dermogeny's pusillus Van Hasselt aufgeklärt.

\section{1. $\operatorname{srol}$}

Department of Histology, Free l'niversity, Amsterdam (The Netherlands), April 1, 1962.

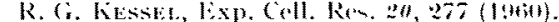

A. Stolk, Nature $39,37,37$ (It)il).

3 O. J. IEtcistr and R. I)Usten, Colchicine (lowa state College Pross, All10 1955$)$.

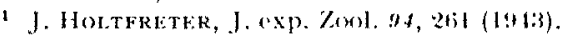

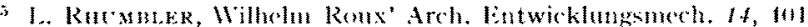
(10)2).

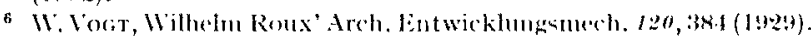

